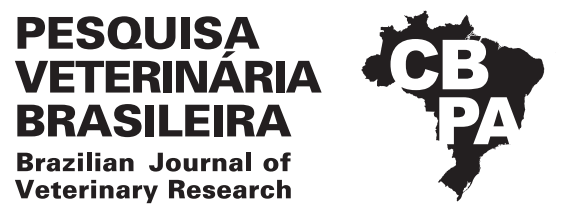

Pesq. Vet. Bras. 39(12):949-953, December 2019 DOI: 10.1590/1678-5150-PVB-6362

Original Article

ISSN 0100-736X (Print)

ISSN 1678-5150 (Online)

\title{
Spontaneous poisoning by Talisia esculenta in cattle ${ }^{1}$
}

\author{
Jaianne K.A. Melo², Gliére S.L. Soares ${ }^{2}$, Taciana R.R. Ramos ${ }^{3}$, \\ Valdir M. Almeida ${ }^{4}$, Ana L.O. Nascimento ${ }^{5}$, Givaldo B. Silva Filho ${ }^{5}$, \\ Hisadora A.S. Chaves ${ }^{5}$ and Fábio S. Mendonça ${ }^{5 *}$
}

\begin{abstract}
Melo J.K.A., Soares G.S.L., Ramos T.R.R., Almeida V.M., Nascimento A.L.O., Silva Filho G.B., Chaves H.A.S. \& Mendonça F.S. 2019. Spontaneous poisoning by Talisia esculenta in cattle. Pesquisa Veterinária Brasileira 39(12):949-953. Laboratório de Diagnóstico Animal, Universidade Federal Rural de Pernambuco, Rua Dom Manoel de Medeiros s/n, Dois Irmãos, Recife, PE 52171-900, Brazil. E-mail: fabio.mendonca@pq.cnpq.br

Talisia esculenta, commonly known as pitombeira, is a tree which fruits are widely consumed by human beings in northeastern Brazil. The aim of this work is to describe the epidemiological, clinical and pathological aspects of two outbreaks of spontaneous poisoning by T. esculenta in cattle in the dry region of Pernambuco, northeastern Brazil. The cases occurred in the municipalities of São Bento do Una and Belo Jardim. From a total of 25 adult cattle, eight become sick after ingest T. esculenta leaves and fruits. Four cattle died until 72 hours after the first clinical signs; which consisted in ataxia, reluctance to walk, tottering, head tremors muscle spasms in the limbs, rigidity of the pelvic limbs with wide base stance position, ruminal atony and, when stressed, presented falls and remained in abnormal positions. Two cattle were necropsied; the only significant finding was the presence of partially digested leaves, barks and seeds of T. esculenta in ruminal contents. Microscopically no lesions were observed. There is no specific therapy for poisoning by T. esculenta leaves. Prophylaxis consists in preventing cattle from gaining access to pasture areas containing the plant.
\end{abstract}

INDEX TERMS: Spontaneous poisoning, Talisia esculenta, cattle, poisonous plants, plant poisoning, ataxia, ruminants.

RESUMO.- [Intoxicação espontânea por Talisia esculenta em bovinos]. Talisia esculenta, popularmente conhecida como pitombeira, é uma árvore cujos frutos são amplamente consumidos por seres humanos no nordeste do Brasil. 0 objetivo deste trabalho é descrever os aspectos epidemiológicos, clínicos e patológicos de dois surtos de intoxicação espontânea por T. esculenta em bovinos no Agreste de Pernambuco, Nordeste do Brasil. Os casos ocorreram nos municípios de São Bento do Una e Belo Jardim De um total de 25 bovinos

\footnotetext{
${ }^{1}$ Received on May 11, 2019.

Accepted for publication on July 10, 2019.

${ }^{2}$ Graduate Program in Veterinary Medicine, Universidade Federal Rural de Pernambuco (UFRPE), Rua Dom Manoel de Medeiros s/n, Dois Irmãos, Recife, PE 52171-900, Brazil.

${ }^{3}$ Universidade Federal Rural de Pernambuco (UFRPE), Unidade Acadêmica de Garanhuns, Avenida Bom Pastor s/n, Boa Vista, Garanhuns, PE 55292-270, Brazil.

${ }^{4}$ Hospital Veterinário, Centro de Saúde e Tecnologia Rural (CSTR), Universidade Federal de Campina Grande (UFCG), Campus de Patos, Patos, PB 58700-000, Brazil.

${ }^{5}$ Laboratório de Diagnóstico Animal, Departamento de Morfologia e Fisiologia Animal, Universidade Federal Rural de Pernambuco (UFRPE), Rua Dom Manoel de Medeiros s/n, Dois Irmãos, Recife, PE 52171-900. *Corresponding author: fabio.mendonca@pq.cnpq.br
}

adultos, oito adoeceram após consumirem as folhas e frutos de T. esculenta. Quatro morreram em até 72 horas após a observação dos primeiros sinais clínicos; que consistiam em ataxia, relutância em caminhar, andar cambaleante, tremores de cabeça, espasmos musculares nos membros, rigidez dos membros pélvicos com posição de ampla base, atonia ruminal e, quando excitados, apresentavam quedas e permaneciam em posições anormais. Dois bovinos foram necropsiados e o único achado significante foi a presença de folhas, cascas e sementes parcialmente digeridas de T. esculenta no conteúdo ruminal. Microscopicamente não foram observadas lesões. Não existe terapia específica para a intoxicação pelas folhas de T. esculenta. A profilaxia consiste em evitar que bovinos tenham acesso às áreas de pastagem contendo a planta.

TERMOS DE INDEXAÇÃO: Intoxicação espontânea, Talisia esculenta, bovinos, plantas tóxicas, intoxicação por plantas, ataxia, ruminantes.

\section{INTRODUCTION}

Talisia esculenta (A. St.-Hil.) Radlk., commonly known as "pitomba" or "pitombeira", is a tree from 5 to 15 meters high (Fig.1) of the Sapindacea family, which produces fruits 


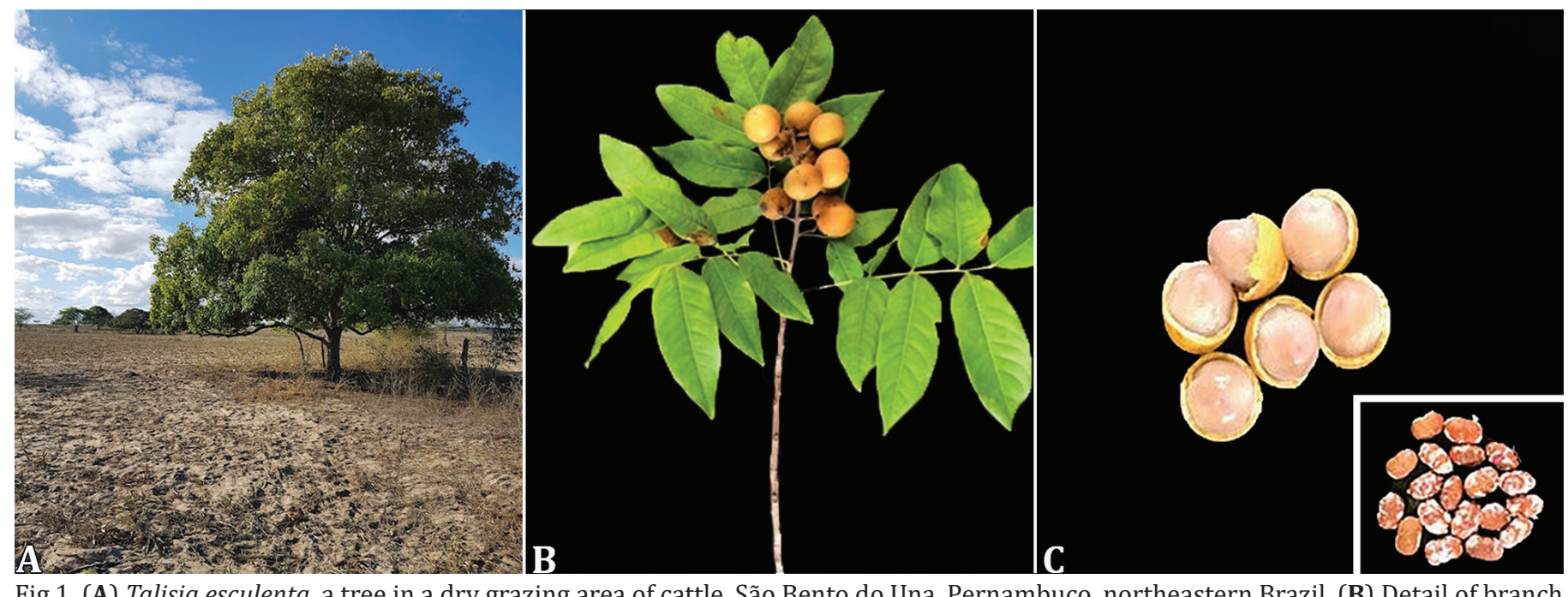

Fig.1. (A) Talisia esculenta, a tree in a dry grazing area of cattle. São Bento do Una, Pernambuco, northeastern Brazil. (B) Detail of branch and fruits. (C) Part of the barks were removed to show the pulp. Inset: brown seeds without pulp.

with up to 2,5cm in length, almost globular with oval brown seeds, which pulp is widely consumed in northeastern Brazil and other regions of the country. This species is found in almost all Brazilian territory, from the Amazon, from where it originates, to Rio de Janeiro and can also be found in other countries such as Paraguay and Bolivia (Guarim-Neto et al. 2003). It has flowering period from August to October with fruit ripening, in some regions, between January and March (Lorenzi 2002).

The use of the pitomba seed tea is used in Brazilian folk medicine as an astringent and the leaves are used with the intent to heal diarrhea, dehydration, and joint and kidney problems in humans (Guarim-Neto et al. 2003). However, despite consumption and use in folk medicine, there are no records of human poisoning because the seeds and leaves are not ingested in natura; just the pulp is normally consumed. However, outbreaks of poisoning in cattle, sheep and dogs that consumed seeds and/or leaves have recently been described (Riet-Correa et al. 2014, Mota et al. 2016, Almeida et al. 2018). The poisoning was also reproduced experimentally in sheep (Riet-Correa et al. 2014). The main toxin of T. esculenta seeds and leaves is still unknown, however, seeds and leaves contain talisin, a lectin that has hemagglutinating erythrocyte activity (Freire et al. 2003).

The aim of this work is to describe the epidemiological, clinical and pathological aspects of two outbreaks of spontaneous poisoning by T. esculenta in cattle in the dry region of Pernambuco, Northeast of Brazil.

\section{MATERIALS AND METHODS}

Epidemiological and clinical data of Talisia esculenta (Sapindaceae) poisoning in cattle were obtained during technical visits in the municipalities of São Bento do Una and Belo Jardim, Pernambuco, in northeastern Brazil.

In São Bento do Una municipality, eight crossbred dairy cattle presented an acute neurological clinical picture. In Belo Jardim, five cattle presented similar clinical neurological signs. From these outbreaks, three cattle were selected for a systematized nervous clinical exam, performed according to Riet Correa et al. (2002).
Their general condition, appetite, color of mucous membranes, rectal temperature, heart and respiratory rates, form of abdomen, and rumen/reticulum motility were recorded. Rumen fluid was also collected to perform laboratory examinations. Examination of rumen fluid was performed according to Dirksen et al. (1993). The pH of the rumen fluid samples was measured at the time of sampling using $\mathrm{pH}$ indicator strips. The color, odor, appearance, sedimentation-flotation, reduction of methylene blue and protozoa activity was analyzed. Density, motility, live-dead ratio and predominance of protozoa were evaluated by direct microscopy (Dehority 1993).

To perform blood count tests, blood samples from each cattle were collected using a vacuum system through puncture of the jugular vein. These samples were stored in two $10 \mathrm{~mL}$ tubes, one with the anticoagulant ethylenediaminetetraacetate acid (EDTA) in a $10 \%$ aqueous solution and the other without anticoagulant. The serum was separated by centrifugation at $2.500 \mathrm{rpm}$ for 10 minutes and maintained at $-20^{\circ} \mathrm{C}$ until analysis.

Two cattle were necropsied after spontaneous death. Samples of the CNS were obtained from the cerebrum, brainstem, cerebellum, diencephalon and spinal cord. Moreover, fragments of liver, kidney, heart, lung, spleen, rumen, reticulum, omasum, abomasum and intestines were collected, fixed in $10 \%$ formalin, processed routinely, stained with hematoxylin and eosin (HE).

Additionally, the cattle grazing areas were inspected in order to find poisonous plants and watch the feeding behavior of the herds.

\section{RESULTS}

The outbreaks occurred in São Bento do Una $\left(8^{\circ} 31^{\prime} 20^{\prime \prime} \mathrm{S}\right.$ $36^{\circ} 26^{\prime} 37^{\prime \prime} \mathrm{W}$ ) and Belo Jardim ( $08^{\circ} 20^{\prime} 08^{\prime \prime} \mathrm{S} 36^{\circ} 25^{\prime} 27^{\prime \prime} \mathrm{W}$ ), in the Ipojuca Valley, dry region of Pernambuco State, northeastern Brazil. The region has a semiarid climate type, with a mean annual rainfall of $890 \mathrm{~mm}$, an average annual temperature of $23.0^{\circ} \mathrm{C}$ and the rainy season is from March to July. The vegetation is composed by hyperxerophilic caatinga and subcaducifolia tropical forest.

The farms where the outbreaks occurred had less than 20ha and had similar management. The herds were left in a non-cultivated feedlot to graze because in the previous years, the region had a long period of drought and the farmers did 
not prepared pastures for cattle feeding. In the morning the herds were left in areas with fresh water and containing Talisia esculenta trees, which were used for the cattle shading and in the afternoon, they were removed to stalls to receive chopped grass and commercial ration.

In São Bento do Una, from a total of ten adult crossbred Holstein cows, three were poisoned from May to June and from these, two died after presenting anorexia, head tremors and in less than 24 hours lateral recumbency and death. One cow with less severe poisoning presented anorexia, adipsia, instability to walk, head and limbs tremors, muscular spams, lateral gait, reluctance to walk and when forced to move presented falls; and after arising remained in wide base stance (Fig.2). The period of evolution until the total recovery was 7 days after removal of the pasture area. During the inspection of the grazing area a total of 15 T. esculenta trees in fructification period were found. The herd consumed the fruits directly from the ground and/or the leaves from the low branches of some trees (Fig.3).

In Belo Jardim five adult crossbred Nelore cattle, from a total of 15 animals in the herd, presented similar neurological clinical signs consisted in congested episcleral vessels, anorexia, ataxia, intense muscles tremors, mainly the head and ears, and constant muscular spasms of the hindlimbs, unusual stance positions and lateral gait followed by fallings to the ground. There was also ruminal atony with moderate bloat. After 24-72 hours two cattle died and were necropsied. At gross examination, the only finding was the presence of seeds and partially digested leaves in the rumen. No microscopically lesions were observed.

The main changes observed in ruminal fluid were decreased of methylene blue activity, and slight reduction of the density and motility of rumen microfauna. No hematological abnormalities were present.
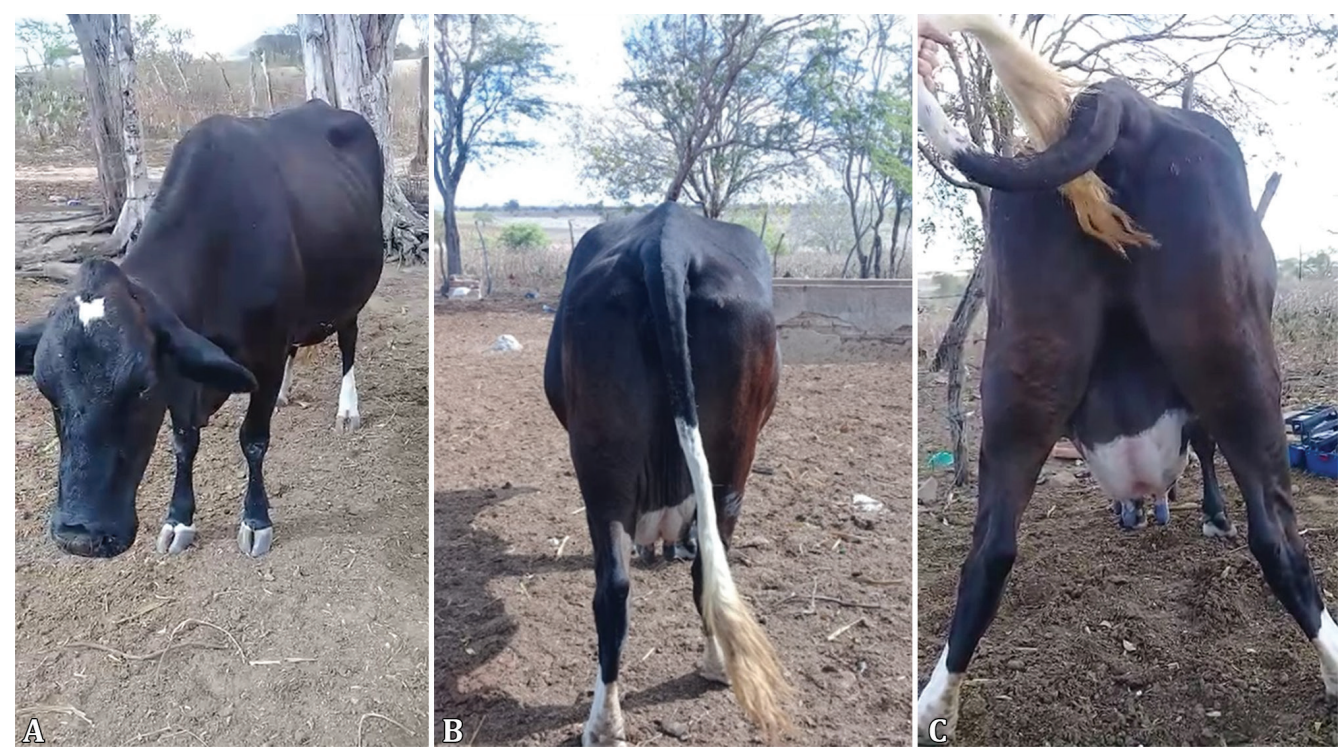

Fig.2. (A) Cattle spontaneously poisoned by Talisia esculenta showing ataxia, mild bloat, (B) difficulty in walking and $(\mathbf{C})$ remaining in wide base stance.

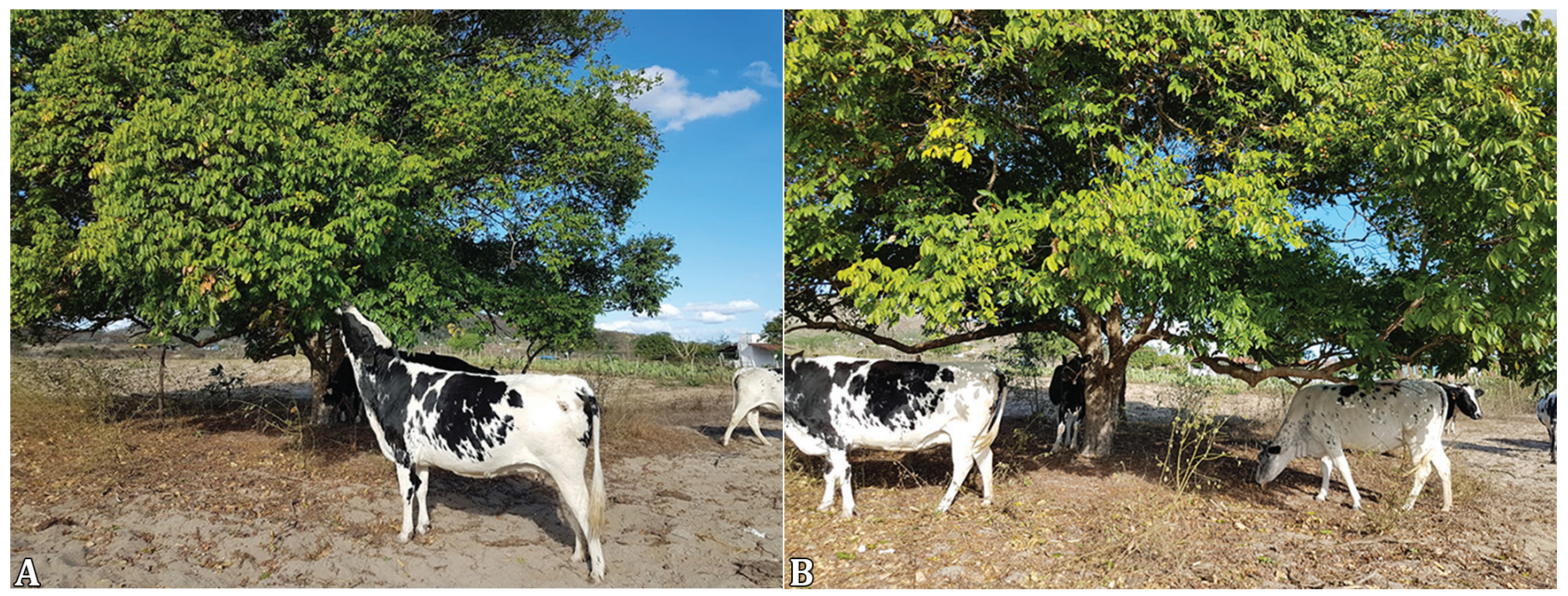

Fig.3. (A) Dairy cow consuming Talisia esculenta leaves and (B) seeds in a grazing area of cattle. 


\section{DISCUSSION}

São Bento da Una and Belo Jardim are municipalities with a dry climate and like other municipalities in the region usually have prolonged drought periods, a factor predisposing to cases of poisoning due to toxic plants ingestion (Tokarnia et al. 2012). However, Talisia esculenta fruits are palatable and are easily consumed by ruminants; if disponible for consuming under the trees, when falling on the ground during fructifying period can cause poisonings outbreaks in ruminants.

Epidemiological and clinical data were similar those previously reports in sheep at Pernambuco (Almeida et al. 2018) and in cattle and sheep at Paraíba (Riet-Correa et al. 2014). The poisoning had acute evolution and cattle presented neuromotor clinical signs after 12 hours after ingestion of fruits and or leaves. However, the bloat with decreased ruminal movements, decreased methylene blue reduction test, and death of rumen protozoa as described in this study, suggest that the digestive system is also affected (Riet-Correa et al. 2014).

In a previous study, the poisoning was reproduced experimentally in five sheep by the administration of $30-60 \mathrm{~g}$ of leaves $/ \mathrm{kg}$ body weight and in two sheep with doses of 5 and $10 \mathrm{~g}$ of seeds $/ \mathrm{kg}$ (Riet-Correa et al. 2014). Toxic doses for cattle remain unknown. The toxic doses of the seeds were smaller than the toxic doses of the leaves, suggesting that the toxic compound is more concentrated in the seeds than in the leaves (Riet-Correa et al. 2014).

No gross or histologic lesions were reported in the sheep or cattle spontaneous or experimentally poisoned by the seeds or leaves of T. esculenta (Riet-Correa et al. 2014, Almeida et al. 2018). The diagnosis should be based on the history of ingestion of seeds or leaves of the plant and the absence of significant gross or histologic lesions. In another hand, the presence of seeds in the rumen content associated to neurological clinical signs has diagnostic value and must be considerate in the diagnosis of this poisoning.

Toxic principles of T. esculenta seeds remains unknown but several reports have shown that reserve proteins act as plant defense against insects and herbivores (Macedo et al. 2011). T. esculenta seeds contain talisin, a reserve protein that act as a storage protein, presenting lectin-like activities i.e. caracterized by a weakly hemagglutination inhibition of human and animal erythrocytes in high concentrations (starting from $500 \mu \mathrm{g} \mathrm{mL}^{-1}$ ) (Freire et al. 2003). In addition, talisin also displays protease-inhibitor properties, as bovine trypsin, and induces neutrophil and mononuclear cell inflammatory response by a mechanism related to specific protein-carbohydrate interactions (Freire et al. 2003, Macedo et al. 2011). These interactions could serve as major signals in some cells causing the release of proinflammatory mediators such as cytokines, nitric oxide and leukotrienes. Additionally, it was reported that talisin has an inhibitory effect of the carbohydrate's glucose and mannose in mice neutrophils and these activities may be related to different affinities of talisin for the glycosyl groups present on the cells surfaces (Freire et al. 2003).

The main differential diagnoses of T. esculenta poisoning are rabies, listeriosis, and botulism, which are common diseases in ruminants in Pernambuco (Riet-Correa et al. 2014). Other neurological poisonous plants, such as Ipomoea spp. and Solanum paniculatum are endemic in northeastern Brazil and should be considerate in the differential diagnosis (Antoniassi et al. 2007, Guaraná et al. 2011, Carvalho et al. 2014, Mendonça et al. 2018).

\section{CONCLUSIONS}

The seeds of Talisia esculenta are palatable and if consumed by cattle cause acute nervous signs.

The leaves are ingested by cattle due to scarcity of food and cause identical clinical signs.

Farmers should avoid planting this plant species in grazing areas of ruminants due to its toxicity.

Acknowledgments.- To the FACEPE (Process APQ-0202- 5.05/17), CAPES (Finance Code 001) and CNPq (Process 304804/2018-5 and 133138/2018-6) for granting the necessary financial support for the development of this study.

Conflict of interest.- The authors have no conflicts of interest to declare.

\section{REFERENCES}

Almeida V.M., Peña-Alfaro C.E., Braga T.C., Lima Filho A.A., Aires L.D.A., Silva Filho G.B., Souza F.A.L. \& Mendonça F.S. 2018. Intoxicação por Talisia esculenta (A. St.-Hil.) Radlk em ovelhas prenhes e em seus neonatos. Pesq. Vet. Bras. 38:330-331.

Antoniassi N.A.B., Ferreira E.V., Santos C.E.P., Arruda L.P., Campos J.L.E., Nakazato L. \& Colodel E.M. 2007. Intoxicação espontânea por Ipomoea carnea subsp. fistulosa (Convolvulaceae) em bovinos no Pantanal Matogrossense. Pesq. Vet. Bras. 27(10):415-418. <http://dx.doi.org/10.1590/S0100736X2007001000005>

Carvalho F.K.L., Dantas A.F.M., Riet-Correa F., Pires J.P.S. \& Silva F.O.R. 2014. Intoxicação por Ipomoea asarifolia em bovinos e ovinos no Rio Grande do Norte. Pesq. Vet. Bras. 34(11):1073-1076. <http://dx.doi.org/10.1590/ S0100-736X2014001100006>

Dehority B.A. 1993. Laboratory Manual for Classification and Morphology of Rumen Ciliate Protozoa. CRC Press Inc., Florida. 96p.

Dirksen G., Gründer H.D. \& Stöber M. 1993. Rosenberger Exame Clínico dos Bovinos. $3^{\underline{a}}$ ed. Guanabara Koogan, Rio de Janeiro. 419p.

Freire M.G., Desouza I.A., Silva A.C., Macedo M.L., Lima M.S., Tamashiro W.M., Antunes E. \& Marangoni S. 2003. Inflammatory responses induced in mice by lectin from Talisia esculenta seeds. Toxicon 42(3):275-280. <http:// dx.doi.org/10.1016/S0041-0101(03)00142-9> <PMid:14559078>

Guarim-Neto G., Santana S.R. \& Silva J.V.B. 2003. Repertorio botânico da "pitombeira" (Talisia esculenta (A. ST.-HIL.) Radlk. - Sapindaceae). Acta Amaz.33(2):237-242. <http://dx.doi.org/10.1590/1809-4392200332242>

Guaraná E.L.S., Riet-Correa F., Mendonça C.L., Medeiros R.M.T., Costa N.A. \& Afonso J.A.B. 2011. Intoxicação por Solanum paniculatum (Solanaceae) em bovinos. Pesq. Vet. Bras. 31(1):59-64. <http://dx.doi.org/10.1590/ S0100-736X2011000100009>

Lorenzi H. 2002. Talisia esculenta, p.322-322. In: Ibid. (Ed.), Árvores Brasileiras: manual de identificação e cultivo de plantas arbóreas nativas do Brasil. $4^{\underline{a}}$ ed. Editora Plantarum, Nova Odessa.

Macedo M.L.R., Freire M.G.M., Kubo C.E.G. \& Parra J.R.P. 2011. Bioinsecticidal activity of Talisia esculenta reserve protein on growth and serine digestive enzymes during larval development of Anticarsia gemmatalis. Comp. Biochem. Physiol. C, Toxicol. Pharmacol. 153(1):24-33. <http://dx.doi. org/10.1016/j.cbpc.2010.08.001><PMid:20692365>

Mendonça F.S., Silva Filho G.B., Chaves H.A.S., Aires L.D.A., Braga T.C., Gardner D.R., Cook D. \& Buril M.T. 2018. Detection of swainsonine and calystegines in Convolvulaceae species from the semiarid region of Pernambuco. Pesq. Vet. Bras. 38(11):2044-2051. <http://dx.doi.org/10.1590/1678-5150pvb-5945>

Mota T.M., Silva A.E.V.N., Melo Filho E.V., Siqueira J.O., Ferreira D.R.C., Groschke H.M. \& Teixeira M.W. 2016. Intoxicação por sementes de 
pitombeira (Talisia esculenta) em um cão - relato de caso. Clin. Vet. 21(125):78-84.

Riet-Correa F., Riet-Correa G. \& Schild A.L. 2002. Importância do exame clínico para o diagnóstico das enfermidades do sistema nervoso em ruminantes e equídeos. Pesq. Vet. Bras. 22(4):161-168. <http://dx.doi.org/10.1590/ S0100-736X2002000400006>
Riet-Correa F., Bezerra C.W., Medeiros M.A., Silva T.R., Miranda Neto E.G. \& Medeiros R.M. 2014. Poisoning by Talisia esculenta (A. St.-Hil.) Radlk in sheep and cattle. J. Vet. Diag. Invest. 26(3):412-417. <http://dx.doi. org/10.1177/1040638714530989><PMid:24760131>

Tokarnia C.H., Brito M.F., Barbosa J.D., Peixoto P.V. \& Döbereiner J. 2012. Plantas Tóxicas do Brasil. Editora Helianthus, Rio de Janeiro. 586p. 